DOI: 10.12731/2077-1770-2021-13-3-212-235

УДК 811.161.1’373.43::392.77

\title{
ИЗДЕВАТЕЛЬСТВО И ПРОВОКАЦИЯ \\ В ЭПОХУ ЛУЛЗОВ: ЛЕКСИКО-СЕМАНТИЧЕСКАЯ РЕПРЕЗЕНТАЦИЯ КОЛЛОКАЦИЯМИ С КЛЮЧЕВЫМИ СЛОВАМИ ГЛУМ, СТЕБ, ПРАНК, ТРОЛЛИНГ
}

\section{Ребрина Л.Н.}

Цель. Исследование направлено на выявление специффики слов, обозначающих деструктивные интерперсональные действия ради развлечения, определение особенностей лексико-семантической репрезентации в современной русскоязычной интернет-коммуникацчии лулзовых издевательства и провокациии посредством анализа именных и глагольно-именных коллокащий.

Метод или методология проведения работы. В качестве репрезентантов изучаемых феноменов на семантических основаниях выбраны существительные глум, стеб, пранк, троллинг. Анализируются структура, субъектность, объектность, внешняя и внутренняя переходность, серии, структурно-семантические модели, тематические коды, прагматический компонент значения коллокаций.

Результаты. Определены структурные, синтагматические, семантические, прагматические особенности отобранных коллокацчий и ключевых слов. Выявлены общие закономерности языковой репрезентации развлекательных издевательств и провокаций и специфика репрезентации феноменов глума, стеба, пранка, троллинга.

Область применения результатов. Результаты могут найти применение в лексикографической практике.

Ключевые слова: коллокация; семантические, структурные, синтагматические признаки; ключевое слово; лексико-семантическая репрезентащия; издевательство; подстрекательство; русская лингвокультура 


\section{SCOFF AND PROVOCATION IN THE ERA OF LULZ: LEXICAL AND SEMANTIC REPRESENTATION THROUGH COLLOCATIONS WITH THE KEYWORDS GLUM, BANTER, PRANK, TROLLING}

\section{Rebrina L.N.}

Purpose. The study aims at identifying the specifics of words denoting destructive interpersonal actions to entertain, determining the features of lexical and semantic representation of lulz bullying and provocation through the analysis of nominal and verb-nominal collocations in modern Russian-language Internet communication.

Methodology. The article analyzes the structure, subjectivity, objectivity, external and internal transitivity, series, structural and semantic models, thematic codes, pragmatic component of the meaning of collocations.

Results. Structural, syntagmatic, semantic, pragmatic features of the selected collocations and keywords are determined. The general patterns of linguistic representation of bullying and provocation for entertainment and the representation specificity of the phenomena of glum, banter, prank, trolling are revealed.

Practical implications. The results can find application in lexicographic practice.

Keywords: collocation; semantic, structural, syntagmatic features; keyword; lexical and semantic representation; scoff; provocation; Russian linguoculture

\section{1. Общество впечатлений, оскорбление и провокации}

как актуальные лулзовые практики

Проблематика исследования связана с актуальным феноменом, характеризующим современное «общество переживаний» / «общество впечатлений» (термин введен Г. Шульце; Erlebnisgesellschaft сегодняшнее, индивидуалистическое, нацеленное на гедонизм, получение наслаждений, потребление, интенсивность жизни здесь и 
сейчас, на борьбу со скукой и меланхолией общество с измененными потребностями, потребительскими установками, рациональностью, регуляцией, с главным поведенческим императивом «Потребляя, переживай свою жизнь, получай впечатления!», в котором переживания, впечатления, эмоции обретают особую ценность (см. $[13 ; 21 ; 22])$. Поведение членов данного общества регламентируют, прежде всего, впечатления, стремление к развлечению. При этом в условиях глобализации информационных и коммуникационных процессов виртуальность тесно переплетается со сложной реальность, бегством от которой и становится развлечение (что обусловливает на фоне снижения роли материальных и биологических потребностей упрощенное отношение к жизни). Лулзы как желаемая цель, оправдывающая и объясняющая поступки, нарушение правил и моральных установок, девиацию; паразитирование на эмоциях других; игровая направленность; изменение роли и функциональных характеристик смеха (а именно, его функционирование в интерперсональной коммуникации как средства экстериоризации участника; интерпретация смехового поведения как демонстрации ума, знания, креативности; неактуальность деления на высокоинтеллектуальный и низменный смех; полифоничность, т.е. обязательность для функционирования активных / интерактивных наблюдателей-участников, вносящих свой вклад, дополняющих и обеспечивающих функциональную целостность; умножение субъектов-адресантов; открытость соответствующих коммуникативных практик; тотальный, всеохватывающий характер объекта смеха) являются следствием развития общества потребления, общества впечатлений на фоне глобализации информационных и коммуникативных технологий и характеризуют актуальный этап эпохи постмодерна [3]. Активное распространение использующего и транслирующего гетеростереотипы языка вражды в постмодернистком обществе обусловливается высоким темпом социальных трансформаций, усложняющейся социальной структурой общества (возникновение множества субкультур и их миксов, географическая мобильность и активные миграционные 
процессы, множественность идентичности членов общества), изменением ценностей, моральных норм и формированием морального нигилизма, активным применением во властном дискурсе стратегии конструирования образа врага для консолидации общества, усложняющей социальные отношения неблагоприятной окружающей средой (финансовый, экономический кризис и пр.) [9]. В упомянутом обществе развлечения и деструктивные интерперсональные действия, например, издевательства, провокации также могут носить лулзовый характер и становиться источником развлечения, удовольствия адресантов и адресатов (от содержания, формы и реакции наблюдателей-участников), что находит отражение в языке.

Объектом исследования выступают коллокации с ключевыми словами (КС), обозначающими названные феномены (издевательство, провокация / подстрекательство ради лулзов), извлеченные из веб-коллекций корпусов текстов. Исследование нацелено на сопоставительную характеристику семантических и синтагматических характеристик КС, выявление закономерностей лексико-семантической репрезентации «развлекательных» издевательства и подстрекательства посредством полиаспектного анализа функционирующих в интернет-коммуникации 2010-2020 гг. коллокаций с данными КС. Анализируемые КС относятся к лексике с семантикой вражды, актуальность изучения и лексикографирования которой обусловливается современными социальными и информационными процессами, когда широкие возможности, предоставляемые сетью Интернет, ведут, в том числе, к растущим разнообразным деструктивным коммуникативным проявлениям. При этом наблюдается дефицит исследований, посвященных систематизации современной русскоязычной лексики вражды. Лексическая репрезентация феноменов лулзовых деструктивных действий в русском языке остается практически не изученной. Между тем, как представляется, лингвистика способна внести свой вклад в осмысление данных феноменов, как и социально значимых процессов и отношений в целом. 


\section{2. Ключевое слово и коллокации как источник информации о лексико-семантической репрезентации фрагмента реальности}

В качестве языковых репрезентантов изучаемых фрагментов современной коммуникативной действительности (издевательство, подстрекательства или провокации ради лулзов) исследуются коллокации с КС глум, стеб, пранк, троллинг, отражающие сегодняшний языковой узус в интернет-коммуникации, представления носителей русского языка об обозначаемом, являющиеся эффективным средством семантизации КС. Перечисленные КС-существительные включены в материал исследования по наличию семантических признаков, указывающих на соответствующие действия (издевательство, провокация), их смеховый, развлекательный характер: 1. Глум - отражаемые в словарных дефинициях семантические признаки «издевательство», «веселое издевательство», «злая насмешка», «издевательская шутка» [1; 4; 8]; 2. Стеб - семантические признаки «провокационная, агрессивная шутка», «скандальный», «осмеивание», «провокативный характер», «дискредитация»; действие по значению стебаться - «злой смех», «словесное издевательство» [2]; 3. Пранк - семантические признаки «шутка», «хулиганство», «провокация ради яркой ответной реакции», «средство для провокации различного рода» [11; 17]; при этом: провокациия - «подстрекательство с какой-н. целью» [1; 4; 8]); 4. Тро́ллингсемантические признаки «в Интернете», «издевательское общение», «социальная провокация», «подстрекательство», «провокационное сообщение», «с целью лулза для себя и догадливых посетителей», «за счет менее догадливых, реагирующих посетителей»; лулз - искаженное англ. «lol»: прикол, рофл, шутка; устойчивые сочетания (всё) ради лулзов (мем - I did it for the lulz), словить лулзов [2; 17]. В отобранной группе КС одинаково представлены русскоязычные и заимствованные из английского языка единицы.

Коллокации рассматриваются нами как статистически устойчивые (свободные или идиоматические), комбинаторно обусловленные, семантически и синтаксически целостные сочетания КС и коллоката, являющиеся типичными для языка / типа текстов / 
сферы коммуникации, т. е. коммуникативными, мнемоническими фрагментами [7; 16; 19]. С позиций контекстно-ориентированных исследований коллокации представляют собой разнородные в семантическом и функциональном планах единицы: общеупотребительные, экспрессивные, авторские (как правило, образованные с нарушением сочетаемости единиц и комбинирования смыслов, использующиеся для выражения субъективного и нетривиального, формирования авторской эстетики), этнокультурные; терминологические [6]. Коллокации, на наш взгляд, - переходные единицы, имеющие промежуточный статус (между словом и конструкцией). Исследуемые коллокации включают именные коллокации (ИК) и глагольно-именные коллокации (ГИК); последние являются образованиями предикативного характера, синтаксическими фраземами, тяготеющими к синтаксическому полюсу [10; 18]. В ИК и ГИК реализуется взаимодействие лексического и синтаксического уровней языка, узуальная актуализация и уточнение значений КС, комбинируемых с разными коллокатами $[12 ; 15 ; 16]$.

Для определения особенностей лексико-семантической репрезентации феномена лулзовых издевательств и подстрекания в русском языке реализуется полиаспектная (структурная, синтагматическая, семантическая) характеристика коллокаций; анализируются количество компонентов, простая / сложная структура словосочетания (отсутствие / наличие других связей помимо связи между КС и коллокатом); субъектность (описание ГИК ситуации как предполагающей наличие одушевленного и / или неодушевленного субъекта действия), объектность (описание ГИК ситуации как предполагающей наличие объекта), внутренняя / внешняя переходность (включение в состав ГИК прямого дополнения / способность ГИК присоединять прямое дополнение); описание серий коллокаций - сочетаний КС и коллоката, имеющих схожую языковую репрезентацию обозначаемых ситуаций (речь идет о сочетаниях КС в одинаковой падежной форме и семантически, синтагматически близких коллокатов) [20], структурно-семантических моделей ИК и ГИК как схематизированных корреляций их структурных и семантических признаков; систе- 
матизация регулярных сфер отождествления денотативных ситуаций (данные сферы обусловливаются семемной структурой значения коллоката; например, в коллокации продажныий глум прилагательное имеет значение «такой, который отдает себя, свои чувства за деньги; такой, которого можно подкупить, который ради денег, выгоды готов на бесчестные поступки» [1] и характеризует глум по аналогии с живым лицом; в коллокации спрятаться за пранк глагол с значением «скрываться от других в каком-л. месте» [Там же] обусловливает интерпретацию денотативной ситуации как разворачивающейся в каком-либо пространстве, а самого явления «пранк» - как некого фрагмента пространства); описание прагматического компонента значений ИК и ГИК [см. Rebrina 2019], выражаемого ценностного отношения к называемому феномену (об отражении ценностных ориентиров в синтагматике см. [5]).

Источник материала - веб-коллекции корпусов Sketch Engine и LEEDS, использующих для извлечения коллокаций аналогичные меры ассоциаций (logDice, Loglikelihood score), оценивающие частотность и совместную встречаемость компонентов коллокации в соотношении с частотностью случайных сочетаний. Общее количество отобранных из веб-коллекций корпусов именных и глагольно-именных коллокаций - единиц (на коллокации с КС приходиться стеб $36,47 \%$ от общей выборки коллокаций; с КС глум - 33,46\%; с КС пранк и троллинг - по 15,035\%). Преобладают ИК: ИК - в материале исследования составляют 71,43\%, ГИК - 28,57\% (с КС глум ИК - 65,17\%, ГИК - 34,83\%; с КС стеб ИК - 78,35\%, ГИК - 21,65\%; с КС пранк ИК - 67,5\%, ГИК - 32,5\%; с КС троллинг ИК - 72,5\%, ГИК - 27,5\%).

\section{3. Лексико-семантическая репрезентация} лулзового издевательства и провокации в русской лингвокультуре через призму многоаспектной характеристики коллокаций

Структурные и синтагматические характеристики коллокаций с КС глум, стеб, пранк, троллинг. Все извлеченные из веб-коллекций корпусов коллокаций с КС глум, стеб, пранк, троллинг имеют 
простую структуру, т. е. реализуют одну грамматическую связь между КС и коллокатом. Большинство коллокаций с названными КС являются двукомпонентными. Трехкомпонентные коллокации представляют собой периферийное явление (с КС глум 5,62\%; с КС стеб 3,31\%; с КС пранк 2,5\%; с КС троллинг - наибольшее количество: 12,5\%), их наличие связано со значимой ролью предлога для обеспечения семантической целостности коллокации, уточнения и реализации значения коллоката. Например: а) в коллокации перейmu / переходить в стеб предлог позволяет отграничить актуализируемое значение глагола «превратиться во что-л. иное, стать чем-л. другим» от других значений коллоката, например, от значения «переместиться, переправиться ... на другую сторону чего-л., ср. перейти улицу [1]; б) в коллокации вылдвать за глум благодаря предлогу отграничивается актуализируемое значение коллоката «представить не тем, что есть на самом деле» от значений «дать, отпустить из места хранения ...; вручить»; сделать известным, открыть ... что-л. скрываемое» [Там же], ср. вылать паек, вылать тайну; в) в коллокации перерастать в троллинг благодаря предлогу актуализируемое значение глагола «обогнать в росте, стать выше кого-, чего-л.» от значения «... превратиться во что-л., перейти во что-л.» [Там же], ср. nерерасти отц̧а. Большая часть исследуемых ГИК являются субъектными коллокациями, описывающими денотативные ситуации как инициируемые активным субъектом: а) с КС троллинг - 81,25\% (преобладают ГИК с предполагаемым одушевленным субъектом - nоддаваться на троллинг; двусубъектные, предполагающие одушевленный или неодушевленный субъект, т.е. двусубъектные скатываться в троллинг (обсуждение скатилось в троллинг; Вы решили скатиться в троллинг?); с неодушевленным субъектом - 25\%, например, смахивать на троллинг; б) с КС стеб - 52,94\% (с одушевленным субъектом - 44,12\%, например, оценить стеб; с неодушевленным субъектом - 8,82\%, например, преврашзаться в стеб); в) с КС глум - 47,62\% (превалируют ГИК с предполагаемым одушевленным субъектом, включая случаи собирательных и персонифицирующих метонимических обозначений - 35,71\%, например, устроить / устраивать 
глум; с неодушевленным субъектом - 11,91\%, например, выродиться в глум); г) с КС пранк - 44,44\% (предполагают одушевленный субъект, например, отомстить за пранк). Менее частотны субъектно-объектные ГИК (т.е. описывающие сопряженные денотативные ситуации как направленные на объект действия субъекта): а) с КС пранк - 33,33\%, например: записать пранк; б) с КС стеб - 32,35\%, например, понять стеб); в) с КС глум - 23,81\%, например, сочинять глум; г) с КС троллинг - 12,5\%, например, прекратить троллинг. Третью группу образуют несубъектные необъектные ГИС, описывающие связанные с лулзовыми издевательствами, подстрекательством ситуации как непроизвольные, не инициируемые субъектом, а соответствующие феномены - как самостоятельные, неконтролируемые (представляют собой периферийное явление, исключение см. (а)): а) с КС глум - 28,57\%, например, глум удался, глум попер, глум ияарит; б) с КС пранк - 22,23\%, например, пранк разыгрывается; в) с КС стеб - 14,71\%, например, стеб обрушивается; г) с КС троллинг - 6,25\%, например, троллинг удался. Относительно характеристики переходности анализируемые ГИК демонстрируют различные тенденции: а) среди ГИК с КС глум превалируют внутренне и внешне непереходные - 33,34\%, например, превратиться в глум (внешне переходные - 9,26\%, например, - 12,96\%, например, устроить глум; аналогичное распределение характеризует ГИК с КС троллинг: преобладают внутренне и внешне непереходные ГИК - вестись на троллинг (внешне переходные - 7,14\%, например, заблокировать за троллинг; внутренне переходные - устроить троллинг); б) среди ГИК с КС стеб наиболее многочисленны -оставить стеб (внешне переходные - 1,92\%, например, пробивает на стеб; внутренне и внешне непереходные - , например, участвовать в cmeбе); в) в группе ГИК с КС пранк одинаково представлены замутить пранквнутренне и внешне непереходные (спрятаться за пранк)- по $20 \%$; не обнаружены внешне переходные коллокации.

Рассмотрим структурно-семантические характеристики анализируемых ИК и ГИК. Результаты анализа указывают на наличие большого количества серий коллокаций, что свидетельствует о 
значимости детальной характеристики денотативной ситуации посредством комбинирования КС с разными семантически и синтаксически близкими коллокатами. Многочленность серии отражает значимость выражаемой характеристики изучаемых коммуникативных феноменов (глум, стеб, пранк, троллинг) для языковой (а именно в языке интернет-коммуникации) и ментальной репрезентации в рамках русской лингвокультуры. В группе Ик и ГИК с КС әлум зафиксировано 18 серий (12 серий ИК, 6 серий ГИК). Наиболее многочленные серии описывают негативное развитие и превращение общения в глум (превратиться / перейти /масштабность его проявления ( / царит); его искусность (изощрённый / тонкий / остроумный глум); большую длительность / повторяемость (продолжстельный / беспрестанный / непрекращающийся глум), неинтенсивность (легкий / неуверенный / несерьёзный глум); нацеленность на определенную группу (глум над детьми / над учителями / над христианами / над оппонентами / над игроками / курящими), на важное, большое, значимое (глум над святым / над кровью / над историей / над страной / над чувствами / над демократией). В группе коллокаций с КС стеб выделено 23 серии (19 серий ИК, 4 серии ГИК). Наиболее значимыми параметрами связанных с феноменом «стеб» денотативных ситуаций являются, описываемыми многочленными сериями являются фиксация восприятия стеба (чувствовать / воспринимать / слушать / читать стеб); негативное развитие ситуации и переход в стеб (уйти / переходить / превращзаться в стеб); жестокость, аморальность (изошренный / жесткий / жестокий / злобный / цииничный / глумливый стеб); искусность, интеллектуальность (находчивый / остроумный / творческий / тонкий / глубиннылй стеб); высокое качество (гениальный / изящный / классный / талантливый / шикарный / хороший стеб); длительность или повторяемость (бесконечный / частый / сплошной / избыточный / повсеместный стеб); авторство стеба (молодежный / шулерский / журналистский / авторский стеб). Коллокации с заимствованными из английского языка КС образуют меньшее количество серий. С КС троллинг выявлено 13 серий (10 серий ИК, 3 серии ГИК). 
Наиболее многочленные серии описывают следующие параметры характеризуемого феномена, связанной с ним денотативной ситуации: типичность троллинга (типичнылй / обыкновенный / очередной троллинг); его искусность (изысканный / изящный / тонкий троллинг) и интеллектуальность (глупый троллинг, бессмысленный троллинг, тупой троллинг); жесткость, интенсивность (жесткий / беспощзадный / интенсивнейший троллинг); распознаваемость (очевидный троллинг явный троллинг, откровенный троллинг); место появления, осуществления (троллинг в соисетях, / в Сети, / в теме, / в комментариях). С КС пранк выявлено 8 серий (7 серий ИК, 1 серия ГИК). Наиболее значимыми, описываемыми самыми многочленными сериями коллокаций параметрами называемого КС феномена и связанных денотативных ситуаций являются высокое качество и воздействующий потенциал пранка (угарный / отвязнылй / звёздный / эпичный / гениальнай / эталонный / незабвенный пранк); его нацеленность на конкретного человека (пранк над девушкой / над парнем / над Евой), используемое средство / инструмент (пранк с заявкой / с пластилином / с шампунью), привлекаемые участники (пранк с гомосексуалистом / с клоуном / со звездами).

Опишем структурно-семантические модели ИК и ГИК, учитывающие компонентный состав, структуру коллокаций, формы компонентов, категориальное значение КС и обобщенное лексическое значение коллокатов. С КС глум выделено 20 структурно-семантических моделей ИК и ГИК. Приведем примеры описания модели: 1) глум над этой биомассой, глум над людьми, глум над народом, глум над овощами, глум над обывателями, глум над детьми, глум над учителями, глум над христианами, глум над оппонентами, глум над игроками - существительное глум и предложная группа с существительным, обозначающим одушевленный коллективный субъект, группу людей; модель: «ЧТО над множеством, группой / в отношении множества, группы людей»; 2) бандеровский глум, раскольнический глум, чиновный глум - притяжательное прилагательное, обозначающее инициатора действия, и существительное глум без предлога; модель: «инициированный кем-то ЧТО». Распростра- 
ненными моделями являются также «ЧТО над объектом культуры / в отношении объекта культуры»; «ЧТО над ценным / в отношении ценного»; «превратиться во ЧТО»; «утонченный ЧТО»; «длительный ЧТО»; «характеризующееся небольшой мерой ЧТО»; «совершается ЧТО»; «есть, становится масштабным ЧТО». В группе ИК и ГИК с КС стеб выделено 24 структурно-семантических моделей. Например: 1) прикольный стеб, забавный стеб, шаловливылй стеб, весельй стеб - определение с обобщенным значением «смешной, забавляющий, развлекающий» и существительное стеб без предлога; модель: «забавляющий ЧТО»; 2) бесконечный стеб, частый стеб, сплошной стеб, избыточный стеб, повсеместный стеб определение с обобщенным значением «в большой мере, широко представленный» и существительное стеб без предлога; модель: «имеющий большую меру ЧТО». Распространенными также являются модели: «не обидный ЧТО»; «качественный ЧТО»; «утонченный ЧТО»; «оригинальный ЧТО»; «масштабный ЧТО»; «злой ЧТО»; «примитивный ЧТО»; «неприличный ЧТО»; «очевидный ЧТО»; «простой ЧТО»; «имеющий определенный временной признак ЧТО»; «осознанный ЧТО»; «исходящий от определенного лица ЧТО»; «не соответствующий обстановке ЧТО»; «воспринимать ЧТО»; «воспринимать с удовольствием ЧТО»; «перейти во ЧТО»; «ЧТО доставляет приятные переживания»; «ЧТО над шаблонным, в от ношении шаблонного»; «ЧТО над определенным / неопределенным единичным / коллективным субъектом, в от ношении определенного / неопределенного субъекта / субъектов»; ЧТО над объектом культуры, мировоззрением, в отношении объекта культуры, мировоззрения». С КС-заимствованиями представлено меньшее количество структурно-семантических моделей. В группе с КС троллинг выделено 13 моделей. Например: 1) жесткий троллинг, беспощьадный троллинг, интенсивнейший троллин - определение с обобщенным значением «характеризующийся высокой степенью интенсивности» и существительное троллинг без предлога; модель: «интенсивный ЧТО»; 2) троллинг в соцсетях, троллинг в Сети, троллинг в теме, троллинг в комментариях-существитель- 
ное троллинг и предложная группа с неодушевленным существительным с обобщенным значением «место вербального действия»; модель: «ЧТО в определенном фрагменте коммуникативного пространства». Приведем другие распространенные структурно-семантические модели ИК и ГИК с данным КС: «утонченный ЧТО»; «явный ЧТО»; «обычный ЧТО»; «примитивный ЧТО»; «неумелый ЧТО»; «глупый ЧТО»; «развитый ЧТО»; «осознанно выстроенный ЧТО»; «уступить воздействию, реагируя на ЧТО»; «превратиться во ЧТО»; «наказать путем исключения за ЧТО». В группе ИК и ГИК с КС пранк выделено 8 структурно-семантических моделей. Например: угарный пранк, отвязный пранк, эпичный пранк, консистентный пранк - определение с обобщенным значением «безудержный, без условностей, с размахом» и существительное пранк без предлога; модель: «безудержный, с размахом ЧТО». Частотными моделями являются также: «превосходный ЧТО»; «рядовой ЧТО»; «ЧТО нарастает»; «ЧТО над конкретной группой лиц или конкретным человеком / в отношении конкретной группы лиц или конкретного человека»; «ЧТО вместе с участником / с помощью участника»; «ЧТО с инструментом- предметом / с помощью предмета».

Важную информацию о ментальной и лексической репрезентации описываемых феноменов предоставляет анализ тематических кодов - регулярных сфер отождествления обозначаемого. Коллокации с КС глум реализуют следующие основные тематические коды, раскрывающие закономерности отождествления описываемого феномена, сопряженных с ним денотативных ситуаций: глум - некто живой (21,32\%, например, нездоровый глум); глум - событие, мероприятие (18,57\%, глум - поступок, проступок (16,58\%, простить за глум); глум - неприятность, негативное воздействие $(15,07 \%$, обрекать на глум); глум - предмет (12,52\%, новыли глум; глум - движущийся объект, фрагмент пространства (7,51\%; гперейти в глум); глум - текст, содержание, общение $(7,03 \%$, сочинять глум; словесный глум). Большей частью ГИК и ИК с КС стеб реализуют персонификацию стеба - 30,35\% (находчивый стеб, здоровый стеб); отождествление стеба с предметом - 15,73\% (дешевый стеб, пло- 
ский стеб); поступком, проступком - 13,48\% (беспричинный стеб, извинять стеб); с текстом, содержанием, общением - 13,36\% (nонятный стеб, эпический стеб, понять стеб); с событием, мероприятием, действием - 9,99\% (неуместный стеб. устроить стеб); с движущимся объектом, фрагментом пространства - 8,94\% (повсеместный стеб, уйти в стеб, переходить в стеб); с неприятностью, негативным воздействием - 2,54\% (воспринимать стеб); с навыком, способностью - 2,25\% (профессиональный стеб). Коллокации с КС пранк реализуют следующие основные тематические коды: пранк - текст, содержание, общение (19,28\%, записать пранк, сльшать / слушать пранк); пранк - предмет (17,95\%, консистентный пранк, спрятаться за пранк); пранк - поступок, действие, проступок (16,26\%, отомстить за пранк); пранк - некто живой (12,96\%, пранк ожил); пранк - воздействие (неприятное) $(11,24 \%$, вестись на пранк); пранк - движущийся объект, фрагмент пространства $(8,98 \%$, пранк распространился); пранк - событие, мероприятие $(7,97 \%$, замутить пранк); пранк - образец (3,34\%, эталонный пранк). Основными тематическими кодами, реализуемыми коллокациями с КС троллинг выступают следующие: троллинг - некто живой $(25,39 \%$, неумельй троллинг, беспощадный троллинг); троллинг - предмет (20,51\%, жесткий троллинг, тонкий троллинг); троллинг - текст, содержание, общение $(14,80 \%$, банальный троллинг, троллинг 8 комментариях); троллинг - событие, мероприятие (14,02\%, устроить троллинг, троллинг удался); троллинг - поступок, проступок (13,31\%, забанить за троллинг, заблокировать за троллинг); троллинг - воздействие (7,32\%, вестись на троллинг, поддаваться на троллинг); троллинг - фрагмент пространства, движущийся объект (2,54\%, скатьвваться в троллинг).

Рассмотрим прагматический компонент значения анализируемых коллокаций для определения транслируемого ИК и ГИК ценностного отношения к «развлекательным» издевательству и провокации, ассоциируемых с ними признаков и образов. Прагматический компонент лексико-семантической репрезентации «развлекательного» издевательства, надсмехательства функционирую- 
щими в русскоязычной интернет-коммуникации коллокациями с КС глум обнаруживает следующие закономерности: а) преобладание нейтральных номинаций $(51,68 \%$, например, словесный глум, продолжительный глум); б) явное доминирование выражаемого ИК и ГИК отрицательного отношения (37,08\%, например, продажный глум, глум надоел) над положительным отношением $(11,24 \%$, например, зачетный глум, остроумный глум); соотношение в подгруппе оценочных обозначений: негативная оценка - 76,74\%; позитивная оценка - 23,26\%. Глум описывается коллокациями как нечто жестокое, проникнутое ненавистью и агрессией, неприятное, нечестное, недостойное, неуместное, наносящее вред, направленное против ценного, важного, неприкосновенного; при этом также как нечто искусное, интеллектуальное, популярное, нацеленное на недостатки. Лексико-семантическая репрезентация лулзового издевательства и провокации посредством ИК и ГИК с КС стеб характеризуется превалированием нейтральных обозначений $(53,61 \%$, например, слушать стеб, чувствовать стебе, участвовать в стебе), незначительным преобладанием выражаемого положительного отношения (26,80\%, например, забавный стеб, здоровый стеб) над отрицательным (19.59\%, например, жестокий стеб, скабрезный стеб); в подгруппе оценочных обозначений: позитивная оценка - 57,78\%; негативная оценка - 42,22\%. Стеб характеризуется как нечто восхищающее своим качеством, интеллектуальностью, искусностью, масштабом, актуальностью, креативностью, как нечто развлекающее, доставляющее положительные переживания, отражающее приятельское отношение; с другой стороны, как нечто злое, жестокое, чрезмерное, неприличное, нарушающее нормы, неприемлемое, мешающее, неудовлетворительного качества, глупое. Языковая репрезентация лулзовой провокации ИК и ГИК с КС пранк характеризуется: а) широко представленными нейтральными обозначениями описываемого феномена соответствующих денотативных ситуаций (75\%, например, задокументированныцй пранк, длиный пранк); б) незначительным превалированием выражаемой положительной оценки (15\%, например, гениальнай пранк, эталонный 
пранк над отрицательной оценкой (10\%, например, пранк надоел, отомстить за пранк); соотношение в группе отражающих оценку коллокаций: позитивная оценка - 60\%, негативная - 40\%. Пранк описывается как нечто веселое, развлекающее, искусное, неординарное, впечатляющее, но, с другой стороны, как нарушающее нормы и правила, недопустимое, нацеленное на ценное. ИК и ГИК с КС троллинг одинаково часто изображают называемый феномен и сопряженные с ним денотативные ситуации как нейтральные или вызывающие оценочное отношение (прим. по 50\%; например, ГИК напоминать троллинг - нейтральное обозначение ситуации); преобладают единицы, отражающие негативное отношение (35\% от общего количества коллокаций; 70\% от конституентов подгруппы оценочных ИК и ГИК; например, скатываться в троллинг, тупой троллинг); наименее представленные коллокации, выражающие позитивное отношение (15\% от общего количества; $30 \%$ от количества выражающих оценочное отношение коллокаций; например, изысканный троллинг, знатный троллинг). Троллиг представляется посредством коллокаций как нечто неуместное, недолжного качества, жестокое, не имеющее смысла, недостойное, неинтеллектуальное, нечестное и превращающее в жертву; с другой стороны, как нечто сложное и искусное, высокого качества, восхищающее, требующее изобретательства, строго следующее цели.

\section{Выводы}

Издевательство, провокация, подстрекательство ради развлечения получают лексико-семантическую репрезентацию посредством именных и глагольно-именных коллокаций с простой структурой, преимущественно, двукомпонентных. Превалируют ИК, что указывает на особую важность в рассматриваемой лингвокультуре отражения характеристики обозначаемых лулзовых деструктивных интерперсональных действий и их объекта (на кого / что направлено). Глагольные коллокации преимущественно описывают сопряженные с лулзовыми издевательством, провокацией, подстрекательством ситуации как инициируемые субъектом, чаще всего, одушевлен- 
ным; реже - как действия субъекта, направленные на обозначаемый развлекательный деструктивный феномен; наименее представлены описания соответствующих ситуаций как непроизвольных, а самих феноменов - как самостоятельных, неконтролируемых. При этом коллокации с разными КС отличаются своей синтагматикой, коррелирующей с такими характеристиками как субъектность, объектность, переходность коллокаций. Коллокации с КС, заимствованными из английского языка (пранк, троллинг), образуют значительно меньше серий. Наиболее значимыми параметрами феноменов и ситуаций их реализации, подлежащими детализации в сериях коллокаций, являются качество, интенсивность, длительность / повторяемость, направленность на определенный объект воздействия, характеристика феномена как результата негативного развития ситуации, что подтверждают описанные структурно-семантические модели Ик и ГИК. Структурно-семантические модели отражают семантическую и синтагматическую специфику КС, ментальные представления носителей языка о называемых феноменах. Обозначаемые феномены, как показывает анализ тематических кодов, отождествляются при их репрезентации посредством ИК и ГИК в основном с живым лицом, предметом, неким текстом или содержанием, поступком или проступком, событием или мероприятием, движущимся объектом или фрагментом пространства, воздействием; большая или меньшая частотность кодов специфична для групп коллокаций с разными КС. Коллокации отражают амбивалентность оценочного отношения носителей языка к обозначаемым феноменам при превалировании в общем количестве исследуемых коллокаций с разными ключевыми КС выражаемой негативной оценки. Позитивная оценка изучаемых феноменов, тем ни менее, также широко представлена. Зафиксированная амбивалентность обусловлена противоположностью оценки объектов, на которые направлены деструктивные действия, эмоционального воздействия и качества действия, его ожидаемости, сложности / простоты.

Выполненный анализ позволил определить специфические семантические и синтагматические характеристики КС глум, стеб, 
пранк, троллинг, лексико-семантической репрезентации обозначаемых ими феноменов. Так феномен троллинга описывается как, преимущественно, инициируемый одушевленным субъектом, но при этом редко как направленное на сам феномен действие субъекта; чаще всего характеризуется относительно его типичности, искусности, агрессивности, интеллектуальности, пагубного воздействия, интенсивности, используемого коммуникативного пространства, следуемого наказания; отождествляется преимущественно с живым лицом или предметом, получает больше негативную (как нечто неуместное, недостойное, жестокое, неинтеллектуальное, грубое), чем положительную оценку. С помощью существительного стеб соответствующие ситуации часто описываются как направленные на называемый феномен действия одушевленного субъекта, что отражается в самом высоком показатели внутренней переходности коллокаций по сравнению с другими исследованными КС; образуемое наибольшее количество серий коллокаций и серий ИК с данным КС отражает популярность и значимость детальной признаковой характеристики данного феномена, а именно его качества, авторства, пагубного воздействия и противоречия морали, искусности, интеллектуальности, продолжительности / повторяемости. Стеб часто интерпретируется как результат негативного развития ситуации; отождествляется прежде всего с живым лицом; получает чаще позитивную оценку (как нечто креативное, масштабное, развлекающее, интеллектуальное, направленное против неценного, шаблонного). Глум по сравнению с других изучаемыми феноменами существенно чаще описывается как нечто самостоятельное, неконтролируемое, связанные с ним ситуации изображаются как непроизвольные; наиболее значимыми, получающими детализацию посредством серий ИК и ГИК параметрами являются масштабность, искусность, временные признаки, интенсивность, направленность на определенный объект, оценка как негативного развития ситуации. Глум отождествляется в первую очередь с живым лицом, событием / мероприятием, поступком / проступком; получает преимущественно негативную оценку (как направленный против ценного, важного, 
неприятный, пагубный, неуместный, нечестный). Пранк одинаково часто описывается как объект действия одушевленного субъекта или как самостоятельная сила; преимущественно отождествляется с текстом / содержанием / общением, предметом, поступком / проступком и получает чаще положительную оценку (как нечто развлекающее, неординарное, искусное); наиболее значимыми параметрами связанных с пранком ситуаций выступают качество, характер воздействия, направленность на некое лицо / группу, используемые средства и участники.

\section{Благодарности}

Исследование выполнено за счет средств гранта Российского научного фонда (проект № 20-68-46003 «Семантика единения и вражды в русской лексике и фразеологии: системно-языковые данные и дискурс» [The study is supported by Russian Science Foundation (project No. 20-68-46003 "The Semantics of Unity and Animosity in Russian Lexis and Phraseology: Language System and Discourse”].

\section{Список литературы}

1. Евгеньева А.П. (общ. ред.) Словарь русского языка: В 4-х т. 4-е изд., стер. РАН, ИЛИ. М.: Полиграфресурсы, 1999. http://feb-web.ru/feb/ mas/MAS-abc/default.asp (дата обращения: 29.08.2021)

2. Картаслов.РУ. Kartaslov. Карта слов и выражений русского языка. https://kartaslov.ru/ (дата обращения: 29.08.2021)

3. Касимов Р.Х. Функционирование смеха в эпоху постиндустриализма // Исторические, философские, политические и юридические науки, культурология и искусствоведение. Вопросы теории и практики. 2012. 4 (18), Ч. I. С. 64-68. https://www.gramota.net/ materials/3/2012/4-1/18.html

4. Кузнецов С.А. (гл. ред.) Большой толковый словарь русского языка. СПб.: Норинт, 2010. http://gramota.ru/slovari/dic/ (дата обращения: 30.08.2021)

5. Маринова Е. Ценностные ориентиры нового времени сквозь призму актуальной сочетаемости слова // Przegląd Wschodnioeuropejski. 2018. № 8(2). C. 273-282. http://uwm.edu.pl/cbew/2017_8_2/Marinova.pdf 
6. Онал И.О. Терминологические коллокации как объект изучения // Научный диалог. 2019. № 1. С. 73-87. https://doi.org/10.24224/22271295-2019-1-73-87

7. Резанова 3., Буб А. Коллокации-биномиалы в русской речи: семантические типы, объективная и субъективная частотность // Quaestio Rossica. 2017. T. 5, № 4. C. 1164-1177. https://doi.org/10.15826/ qr.2017.4.273

8. Ушаков Д.Н. (ред.) Толковый словарь русского языка. https://gufo. me/dict/ushakov/\%D0\%B3\%D0\%BB\%D1\%83\%D0\%BC (дата обращения: 30.08.2021)

9. Фадеичева М.А. Экзистенциальные основания языка вражды // Дискурс-Пи. 2015. № 1 (18). С. 20-24. https://madipi.ru/journals/show/ ekzistencialnye_osnovaniya_yazyka_vrazhdy

10. Ягунова Е.В., Пивоварова Л.М. От коллокаций к конструкциям // Acta linguistica petropolitana. 2014. Vol. X, part 2. C. 568-618. https:// iling.spb.ru/pdf/alp/alp_X_2.pdf

11. Academic - Словари на Академике. https://dic.academic.ru/ (дата обращения: 29.08.2021)

12. Echeverria S.A. Committing crimes and issuing sentences: collocations in corpus studies. Past and future // Lengua y habla. 2019. Vol. 23, pp. 131-156.

13. Illouz E. Cold Intimacies: The Making of Emotional Capitalism. Cambridge: Polity Press, 2007. 134 p.

14. Kang B.M. Collocation and word association: comparing collocation measuring methods // International journal of corpus linguistics. 2018. Vol. 23, No 1. pp. 85-113. https://doi.org/10.1075/ijcl.15116.kan

15. Lai H.L. Collocation analysis of news discourse and its ideological implications // Pragmatics. 2019. Vol. 29, No 4, pp. 545-570. https://doi. org/10.1075/prag.17028.lai

16. Lin Z., Jin Sh. Metonymic and metaphoric meaning extensions of Chinese FACE and its collocations // Pragmatics and society. 2019. Vol. 11, No 1, pp. 96-123. https://doi.org/10.1075/ps.17008.lin

17. Lurkmore. Русскоязычная энциклопедия фольклора и субкультур. http://nouveau.lurkmore.to/ (дата обращения: 30.06.2021) 
18. Masini F. Multi-word expressions between syntax and the lexicon: the case of Italian verb-particle constructions // Journal of linguistics. 2005. № 18, pp. 145-173. http://www.linguistics.fi/julkaisut/SKY2005/Masini. pdf

19. Phoocharoenil S. Semantic prosody and collocation: A corpus study of the near-synonyms persist and persevere // Eurasian journal of applied linguistics. 2021. Vol. 7, No 1, pp. 240-258. http://dx.doi.org/10.32601/ ejal.911269

20. Rebrina L. Representation of memory processes by verbal collocations with the semantic component "time" // XLinguae. 2019. Vol. 12, No 3, pp. 249-265. http://dx.doi.org/10.18355/XL.2019.12.03.19

21. Rössel J. Die Erlebnisgesellschaft zwischen Sozialstrukturanalyse und Zeitdiagnose // Österreichische Zeitschrift für Soziologie. 2003. 28, S. 82-101. https://doi.org/10.1007/s11614-003-0012-0

22. Schulze G. Die Erlebnisgesellschaft. Kultursoziologie der Gegenwart. 2. Aufl. Frankfurt: Campus Verlag, 2005, 612 S.

\section{References}

1. Evgen'eva A.P. (ed.) Slovar'russkogo yazyka: v 4- $h t$. [Dictionary of the Russian language: in 4 volumes]. Moscow: Poligrafresursy, 1999. http:// feb-web.ru/feb/mas/MAS-abc/default.asp

2. Kartaslov.RU. Karta slov $i$ vyrazhenij russkogo jazyka [Map of words and expressions of the Russian language]. https://kartaslov.ru/ (accessed 29.08.2021)

3. Kasimov R.Kh. Funkcionirovanie smeha v jepohu postindustrializma [Laughter functioning in post-industrialism era]. Istoricheskie, filosofskie, politicheskie i yuridicheskie nauki, kul'turologiya i iskusstvovedenie. Voprosy teorii i praktiki [Historical, philosophical, political and legal sciences, cultural studies and art history. Questions of theory and practice], 2012, vol. 4(18), part I, pp. 64-68. https:/www.gramota.net/ materials/3/2012/4-1/18.html

4. Kuznecov S.A. (ed.) Bol'shoj tolkovyj slovar' russkogo yazyka. St. Petersburg [The unabridged dictionary of the Russian language]: Norint, 2010. http:/gramota.ru/slovari/dic/ (accessed 30.08.2021) 
5. Marinova E. Present-day Value Orientations through the Prism of Actual Word Compatibility. Przeglad Wschodnioeuropejski, 2018, vol. 8, no. 2, pp. 273-282. http://uwm.edu.pl/cbew/2017_8_2/Marinova.pdf

6. Onal I.O. Terminologicheskie kollokacii kak objekt izuchenija [Terminological collocation as object under study]. Nauchnyi dialog [Scientific dialogue], 2019, no. 1, pp. 73-87. https://doi.org/10.24224/2227-12952019-1-73-87

7. Rezanova Z., Bub A. Kollokacii-binomialy v russkoj rechi: semanticheskie tipy, objektivnaja i subjektivnaja chastotnost' [Binomials in russian speech: semantic types and objective and subjective frequency]. Quaestio Rossica, 2017, no. 5(4), pp. 1164-1177. https://doi.org/10.15826/ qr.2017.4.273

8. Ushakov D.N. (ed.) Tolkovyj slovar' russkogo yazyka [The explanatory dictionary of the Russian language]. https:/gufo.me/dict/ushakov/\%D0\%B3\%D0\%BB\%D1\%83\%D0\%BC (accessed 31.08.2021)

9. Fadeicheva M.A. Jekzistencial'nye osnovanija jazyka vrazhdy [Existential foundations of hate speech]. Diskurs-P, 2015, vol. 1, no. 18, pp. 20-24.https://madipi.ru/journals/show/ekzistencialnye_osnovaniya_yazyka_vrazhdy

10. Yagunova E.V., Pivovarova L.M. Ot kollokacij k konstrukciyam [From collocations to constructions]. Acta linguistica petropolitana, 2014, vol. X, part 2, pp. 568-618. https://iling.spb.ru/pdf/alp/alp_X_2.pdf

11. Academic - Slovari na Akademike [Academic - Dictionaries on Academic]. https://dic.academic.ru/ (accessed 29.08.2021)

12. Echeverria S.A. Committing crimes and issuing sentences: Collocations in corpus studies. Past and future. Lengua y habla, 2019, 23, pp. 131-156.

13. Illouz E. Cold Intimacies: The making of emotional capitalism. Cambridge: Polity Press, 2007. 134 p.

14. Kang B.M. Collocation and word association: comparing collocation measuring methods. International journal of corpus linguistics, 2018, vol. 23, no. 1, pp. 85-113. https://doi.org/10.1075/ijcl.15116.kan

15. Lai H.L. Collocation analysis of news discourse and its ideological implications. Pragmatics, 2019, vol. 29, no. 4, pp. 545-570. https://doi. org/10.1075/prag.17028.1ai 
16. Lin Z., Jin Sh. Metonymic and metaphoric meaning extensions of Chinese FACE and its collocations. Pragmatics and society, 2019, vol. 11, no. 1, pp. 96-123. https://doi.org/10.1075/ps.17008.lin

17. Lurkmore. Russkojazychnaja jenciklopedija fol 'klora i subkul'tur [Russian-language encyclopedia of folklore and subcultures]. http://nouveau. lurkmore.to/ (accessed 30.06.2021)

18. Masini F. Multi-word expressions between syntax and the lexicon: the case of Italian verb-particle constructions. Journal of linguistics, 2005, vol. 18, pp. 145-173. http://www.linguistics.fi/julkaisut/SKY2005/Masini.pdf

19. Phoocharoenil S. Semantic prosody and collocation: A corpus study of the near-synonyms persist and persevere. Eurasian journal of applied linguistics, 2021, vol. 7, no. 1, pp. 240-258. http://dx.doi.org/10.32601/ejal.911269

20. Rebrina L. Representation of memory processes by verbal collocations with the semantic component "time". XLinguae, 2019, vol. 12, no. 3, pp. 249-265. http://dx.doi.org/10.18355/XL.2019.12.03.19

21. Rössel J. Die Erlebnisgesellschaft zwischen Sozialstrukturanalyse und Zeitdiagnose. Österreichische Zeitschrift für Soziologie, 2003, 28, S. 82-101. https://doi.org/10.1007/s11614-003-0012-0

22. Schulze G. Die Erlebnisgesellschaft. Kultursoziologie der Gegenwart. 2. Aufl. Frankfurt: Campus Verlag, 2005, 612 S.

\section{ДАННЫЕ ОБ АВТОРЕ}

Ребрина Лариса Николаевна, ведущий научный сотрудник, профессор кафедры германской и романской филологии, доктор филологических наук; ведущий научный сотрудник кафедры языков массовой коммуникации

Волгоградский государственный университет; Уральский федеральный университет имени первого Президента России Б.Н. Ельцина

пр. Университетский, 100, г. Волгоград, Волгоградская область, 400062, Российская Федерачия; ул. Мира, 19, г. Екатеринбург, Свердловская область, 620002, Российская Федерачия

LNrebrina@volsu.ru 


\section{DATA ABOUT THE AUTHOR}

Larisa N. Rebrina, Leading Scientific Worker, Professor, Department of German and Roman Philology, Doctor of Philology; Leading Research Scientist, Department of Mass Communication Languages

Volgograd State University; Ural Federal University named after the First President of Russia B. N. Yeltsin

100, Prospekt Universitetskiy, Volgograd, 400062, Russian Federation; 19, Mira Str., Ekaterinburg, 620002, Russian Federation LNrebrina@volsu.ru

ORCID: 0000-0003-0512-980X

SPIN-code: 3971-1615

ResearcherID: G-6420-2015

Scopus Author ID: 56241972800 